\section{Lexicon from the laboratory}

\section{Gareth Jones}

The Dictlonary of Cell Blology. Edited by J. M. Lackie and J. A. T. Dow. Academic: 1989. Pp.262. Hbk £19, \$34.95; pbk £9.95.

DO WE need a dictionary for cell biologists? Virtually all the teaching staff in the cell biology department of the University of Glasgow seem to feel that we do, not so much for our own use but for those whom we teach. The editors state that the aim of this book is to provide students and other "learners" with a quick and painless introduction to the common jargon of cell biology, providing very brief descriptions of a vast range of words and abbreviations compiled from the indexes of the chief textbooks and the key-word libraries of prestigious journals.

Although the editors and authors can be praised for the excellent idea, the execution must have been fraught with problems. It takes only a casual glance through the book to see that conflicts must have arisen constantly between the demands for brevity and for clarification. Whereas the reader of a standard dictionary might be satisfied by the definition of "dermis" as "of the skin", a student would need more, but how much more - is "mesodermally-derived connective tissue underlying the epithelium of the skin" enough? Two methods have been used here to address this problem. There is some crossreferencing, which allows the persistent reader to follow through a definition. There is also the much more useful ploy of providing tables, such as for the classes of intermediate filaments, which provide more of the data really needed by a student cell biologist.

Whatever other attributes one could wish for this book, the very nature of a dictionary demands that the definitions are accurate. Only the very best of us can honestly say that they are not unduly influenced by what they read versus what they are told in lectures, for instance. Unfortunately, I found rather too many errors for my liking, most starkly demonstrated in a table of the classification of integrin subtypes, where the alpha- and beta-chain designations are transposed.

Despite these criticisms, I think the authors and editors have made a good start in their praiseworthy attempt to provide easy access to words in common usage. I suspect any future editions will see longer entries, with expanded use of tables, and closer attention to detail.

Gareth Jones is in the Anatomy Department, Division of Biomedical Sciences, King's College, Strand, London WC2R 2LS, UK.

\section{Following the rise of the Sun}

\section{Koscak Maruyama}

The Formation of Sclence in Japan: Building a Research Tradition. By James R. Bartholomew. Yale University Press: 1989. Pp.371. \$36, £25.

Although Japan's GNP is one of the highest in the West, what is the quality of its science? Few Japanese scientists are prepared to speak out on this issue, an exception being Nobel physicist Leo Esaki, who openly states his belief that Japan has failed to shake free of its reputation for imitative, rather than original, scientific research. Japan's technological strength does not emerge from a broad base of original ideas, and the country's contribution to learning is minimal, in Esaki's view, because Japanese society is group-orientated. On the face of it, these statements seem correct - there have been only 5 Japanese Nobel laureates in science out of a total of 395 winners.

But are the characteristics of efficient imitation and group solidarity alone, as suggested by Esaki, sufficient to explain Japan's economic success? Most Japanese scientists would hesitate to become involved in this controversial question, but the author of this book, who is from the United States, has attempted to address it. Bartholomew explains the unique background to the growth of modern scientific research in Japan, emphasizing the pockets of genuine originality that existed despite the great handicap to growth and development caused by the country's isolation from the West between 1639 and 1853. Bartholomew points out that Esaki's pessimism is not entirely justified - Esaki's own discovery of the tunnel diode effect was made in Japan, although at a company institute rather than a university.

During the Tokugawa period in Japan (1600-1867), individualism was inhibited by the feudalistic nature of society and a strict caste system. Physicians trained in the Chinese tradition helped to introduce Western medicine, and Dutch medical scientists at Nagasaki, who were Japan's only regular contact with Europe, provided some exposure to Western ideas - the Dutch edition of J. A. Kalmus's Anatomische Tabellen (1772) was translated into Japanese, for example. Some scientific progress was made. Seishu Hanaoka excised a breast tumour under general anaesthesia in 1805,40 years earlier than the famous ether anaesthesia performed at Massachusetts General Hospital. Takakazu Seki devised a limited form of calculus and Tobei Kunitomo observed sunspots in 1835 , publishing a drawing of the surface of the Moon obtained by the use of a hand-held telescope. But on the whole, science did not properly develop during the period of isolation, one reason being the Confucian morality that students should not under any circumstances oppose their teachers.

When Meiji (restoration/modernization) began in 1868 , most Japanese scientists were capable only of transcribing foreign books, although there were a few people who could do original research, particularly in the field of medicine. The new government sent many young scientists to the West, mainly Germany, the United States, Great Britain and France. As an example, Bartholomew refers to Shibasaburo Kitasato (rather excessively, on more than 60 occasions!) who learned bacteriology from a Dutch navy doctor at a local medical shcool and, after graduation from Tokyo University, went to Germany to study under Robert Koch in the late nineteenth century. Kitasato isolated tetanus bacteria, produced tetanus and diphtheria vaccines, and established the concept of immunity in collaboration with E. von Behling. Bartholomew argues that Kitasato should have shared the first Nobel prize with von Behling. After his return to Japan, Kitasato established a private institute for infectious diseases in Tokyo, which later became a national institute under the Ministry of home Affairs. Kitasato discovered that Pusteurella pestis was the cause of the plague in 1894. He gave up the directorship of the institute when infighting among its academics forced its transfer to the Ministry of Education. Kitasato created another institute, the Kitasato Institute in Tokyo, with various eminent collaborators. Bartholomew's description of Japanese academic and bureaucratic factionalism is vivid and exciting.

Another of Bartholomew's examples is Katsusaburo Yamagiwa (1863-1930), Professor of Pathology at Tokyo University. In 1914, Yamagiwa was the first to succeed in producing cancer in a rabbit, which he did by repeatedly applying coal tar to its ear. The active substance producing the effect, 3,4-benzpyrene, was identified by E. L. Kennaway in 1932 . Bartholomew contends that the Nobel prize committee made a great mistake in omitting to nominate Yamagiwa for the 1926 prize, which was given to J. Fiebiger for his erroneous theory of the cause of cancer.

It was not easy for scientific institutions to be created in Japan. Tokyo University was founded in 1877, and Bartholomew gives details of the founding of Kyoto, Kyushu, Hokkaido and Tohoku universities. The founding of the Research Institute for Physics and Chemistry in 1917 is noteworthy because this institute, half supported by the state, produced 